2014

\title{
The Constitutional Thought of Alexander Hamilton
}

Mortimer N.S. Sellers

University of Baltimore School of Law, msellers@ubalt.edu

Follow this and additional works at: http://scholarworks.law.ubalt.edu/fac_bookchapters

Part of the Constitutional Law Commons, and the Legal History Commons

\section{Recommended Citation}

Sellers, Mortimer N.S., "The Constitutional Thought of Alexander Hamilton" (2014). Book Chapters. 3.

http://scholarworks.law.ubalt.edu/fac_bookchapters/3

This Book Chapter is brought to you for free and open access by the Faculty Scholarship at ScholarWorks@University of Baltimore School of Law. It has been accepted for inclusion in Book Chapters by an authorized administrator of ScholarWorks@University of Baltimore School of Law. For more information, please contact snolan@ubalt.edu. 


\title{
Constitutions and the Classics
}

\author{
Patterns of Constitutional Thought from
}

Fortescue to Bentham

Edited by

D. J. GALLIGAN 


\section{OXFORD \\ UNIVERSITY PRESS}

Great Clarendon Street, Oxford, OX2 6DP,

United Kingdom

Oxford University Press is a department of the University of Oxford.

It furthers the University's objective of excellence in research, scholarship, and education by publishing worldwide. Oxford is a registered trade mark of

Oxford University Press in the UK and in certain other countries

(c) The several contributors 2014

The moral rights of the authors have been asserted

First Edition published in 2014

Impression: 1

All rights reserved. No part of this publication may be reproduced, stored in a retrieval system, or transmitted, in any form or by any means, without the prior permission in writing of Oxford University Press, or as expressly permitted

by law, by licence or under terms agreed with the appropriate reprographics rights organization. Enquiries concerning reproduction outside the scope of the above should be sent to the Rights Department, Oxford University Press, at the address above

You must not circulate this work in any other form and you must impose this same condition on any acquirer

Crown copyright material is reproduced under Class Licence

Number C01P0000148 with the permission of OPSI and the Queen's Printer for Scotland

Published in the United States of America by Oxford University Press

198 Madison Avenue, New York, NY 10016, United States of America

British Library Cataloguing in Publication Data

Data available

Library of Congress Control Number: 201494235

ISBN 978-0-19-871498-9

Printed and bound by

CPI Group (UK) Ltd, Croydon, CR0 4YY

Links to third party websites are provided by Oxford in good faith and for information only. Oxford disclaims any responsibility for the materials

contained in any third party website referenced in this work. 


\title{
16 \\ The Constitutional Thought of Alexander Hamilton
}

\author{
M. N. S. Sellers
}

\section{Introduction}

Alexander Hamilton's influence on modern constitutionalism arises primarily from his pre-eminence in promoting and interpreting the Constitution of the United States to Americans and to the world, but he also played a central role in creating out his life, and believed has sacrificed or done mith reason, that 'perhaps no man in the United States this observation at the end of the present Constitution than myself.' ${ }^{\prime} \mathrm{He}$ made Hamilton was excluded from career when his political enemies were ascendant, made it clear (as even Hamil government, and the judgement of the people had for me'. ${ }^{2}$ Hamilton's ultimate deat mat this American world was not made the Constitution of the United Stat marks the true measure of his contribution to the election of Thomas Jefferson to the pro constitutionalism more broadly. After intervention), Hamilton delivered his politicancy (secured in part by Hamilton's ing constiturional republic. Alexander H worthless fabric' ${ }^{3}$ of the United States Consilton so well established the 'frail and be needed (or seen) again in the politics of thition that men of his stature would not

1 Alexander Hamilton to Gouverneur Morris, 29 February 1802. This letter and a well selected collection of the most important writings of Alexander Hamilton are conveniently collected in A. Hamilton, Writings, ed. J. B. Freeman (New York: The Library of America, 2001), 986. The most H. C. Syrett (Now Yor Hamilton, The Papers of Alexander Hamilton, ed.

2 . Syrett (New York: Columbia University Press, 1961-1979).

Hamilton to Morris, 29 February 1802.

4 Hamilton to Morris, 29 February 1802.

${ }^{4}$ Recent volumes on Alexander Hamilton and the United States Constitution include M. Meyerson, Liberty's Blueprint: How Madison and Hamilton Wrote the Federalist Papers, Defined the ConstituEffective Republic: Administration the World (New York: Basic Books, 2008); H. Flaumenhaft, The NC: Duke University Press, 199 and Constitution in the Thought of Alexander Hamilton (Durham, Interpretation of Stourh. Alanham: University Press of America, 1991); G. Stourzh, Alexander Hamilton and the Idea of Republican Government (Stanford: Stanford University 1970). 
Hamilton was, with George Washington, the most tireless proponent of American federalism. He was, with James Madison, the most persuasive advocate of the United States Constitution. He was decisive in securing constitutional ratification in recalcitrant New York. As a member of Washington's cabinet, he was the primary architect of the constitution's actual application to government. But, like his friend Gouverneur Morris, Hamilton always remained 'an exotic' in North America. ${ }^{5}$ Born on the Caribbean island of Nevis in unfavourable and somewhat louche circumstances, and raised on anarchic St. Croix, he escaped to New York as a teenager on the strength of his pen and his wit. ${ }^{6}$ Hamilton's influence, reputation, and political career began in 1774 when he offered a 'Full Vindication of the Measures of the Congress, from the Calumnies of their Enemies'. ${ }^{7} \mathrm{He}$ was not yet twenty years old. ${ }^{8} \mathrm{He}$ followed with 'A more Impartial Comprehensive View of the Dispute between Great Britain and the Colonies" and so it would continue for the rest of his life. Hamilton found himself, grew up, and triumphed with the United States of America, and the nation's constitutional project was his too, from the beginning.

When Alexander Hamilton embraced as a youth 'the cause of virtue and mankind', ${ }^{10}$ he adopted the programme, attitudes, and vocabulary of a current of thought present in Britain and her empire for generations, ${ }^{11}$ and in European political culture for centuries before. ${ }^{12}$ The innovation of the American revolutionaries was not in their principles, which they borrowed from English commonwealth ideology ${ }^{13}$ and from republican Rome, ${ }^{14}$ but in their attention to the details

${ }^{5}$ Hamilton to Morris, 29 February 1802, in Hamilton, Writings, 986.

${ }^{6}$ For an entertaining account of Hamilton's childhood and youth, see J. T. Flexner, The Young Hamilton: A Biography (Boston: Little Brown, 1978).

7 A Friend to America [Alexander Hamilton], A Full Vindication of the Measures of the Congress, from the Calumnies of their Enemies (James Rivington, 1774); also found in Hamilton, Writings, $10 \mathrm{ff}$.

8 The year of Alexander Hamilton's birth has been disputed. His own account of 1757 has been called into question. Perhaps it was as early as 1755 .

9 A Friend to America [Alexander Hamilton], The Farmer Refuted: or A more Impartial and Comprehensive View of the Dispute Between Great Britain and the Colonies (James Rivington, 1775).

10 The Farmer Refuted, 43.

11 I have set out the nature and origins of American constitutionalism at length in M. N. S. Sellers, American Republicanism: Roman Ideology in the United States Constitution (Basingstoke: Macmillan, 1994); cf. B. Bailyn, The Ideological Origins of the American Revolution (Cambridge, MA: Harvard University Press, 1967); J. Adams, Defence of the Constitutions of Government of the United States of America (London: Dilly, 1787-8).

12 For more detail on the origin of these ideas and their history, see M. N. S. Sellers, The Sacred Fire of Liberty: Republicanism, Liberalism and the Law (Basingstoke: Macmillan, 1998); cf. M. van Gelderen and Q. Skinner (eds), Republicanism: A Shared European Heritage (Cambridge: Cambridge University Press, 2009).

${ }_{13}^{13}$ In addition to the works cited above (n. 12), see C. Robbins, The Eighteenth-Century Commonwealthman: Studies in the Transmission, Development and Circumstance of English Liberal Thought from the Restoration of Charles II until the War with the Thirteen Colonies (Cambridge, MA: Harvard University Press, 1959); Z. S. Fink, The Classical Republicans: An Fssay in the Recovery of a Pattern of Thought in Seventeenth-Century England, 2nd ed. (Evanston: Northwestern University Press, 1962).

${ }^{14}$ In addition to the works cited above (nn. 12-13), see D. J. Bederman, The Classical Foundations of the American Constitution (Cambridge: Cambridge University Press, 2008); J. C. Richard, The Founders and the Classics: Greece, Rome and the American Enlightenment (Cambridge, MA: Harvard University Press, 1994). 
of constitutional reform, and their willingness to attempt republican government on a continental scale-something not considered possible in Europe, and only ever applied before on the most restricted geographical basis. ${ }^{15}$ Americans sought to apply 'reason' and 'experience' to the 'science of politics', ${ }^{16}$ 'establishing good government by reflection and choice', ${ }^{17}$ to secure the 'liberty', the 'dignity', and the 'happiness' of the people. ${ }^{18}$

\section{Continentalism}

Alexander Hamilton began his adult life as an officer in the Continental Army, abandoning his studies in 1776 to serve as a captain in the artillery and then, when his heroism and literary ability came to the attention of George Washington, as aide-de-camp and principal drafter of letters, orders, and all manner of reports for the commander-in-chief. More than five years' service in this cosmopolitan setting, among the men of all colonies who suffered most to establish American independence, confirmed for Hamilton (as for most continental officers) his impatience with localism, his dissatisfaction with the weakness of existing federal institutions, and his strong desire to improve the power and the credit of the United States. This latter point is particularly important, because it determined the partisan divide that would create and then challenge the United States Constitution. Almost all participants in the Revolution shared a commitment to what they called 'republican principles' in general and to the republican form of government in particular, including the separation of powers, an elected executive, a bicameral legislature, independent judges, and fundamental human rights. ${ }^{19}$ The patriots differed among themselves primarily on whether the dominant locus of republican government should be in the federal government or in the states. Hamilton took the 'federalist' side in this debate from the beginning. ${ }^{20}$

Alexander Hamilton began his fight for a stronger federal constitution by writing six essays in 1781 as the 'Continentalist', in which he sought to counter the 'extreme jealousy of power' that is 'attendant upon all popular revolutions' by

15 On the impossibility of large republics, see Montesquieu, C. de Secondat, baron de la Brède et de, De L'Esprit des Lois (1748), I. viii.16; J. Rousseau, Du Contrat Social (1762), III.1;16.

${ }^{16}$ See 'Publius' [Alexander Hamilton], The Federalist No. 9 in The Independent Journal (November University Press, 2003), 36.
Uall (ed.), The Federalist, with Letters of Brutus (Cambridge: Cambridge 17 'Publius' [Hamilton], The Federalist No. 1 in The Independent Journal (27 October 1787) in Ball,
The Federalist, 1 .

18 Federalist No. 1, at 3.

19 For a detailed discussion of this widely shared republican ideology, see Sellers, American Republicanism.

${ }^{20}$ For a good discussion of Hamilton's political career, see F. McDonald, Alexander Hamilton: A Biography (New York: W. W. Norton, 1979). 
vastly extending the authority of the Federal Congress. ${ }^{21}$ The government as constituted by the Articles of Confederation was incapable, Hamilton argued, either of a vigorous prosecution of war, or the preservation of the Union in peace. ${ }^{22}$ The United States needed enough authority 'to make and execute the laws with vigour'. ${ }^{23}$ Hamilton applied 'experience and reason' 24 to the problems of the confederation, to illustrate the dangers of ceding too much authority to the separate states. ${ }^{25}$ The Continentalist regretted that Congress, charged with the administration of public affairs, lacked the 'means necessary to fulfil that responsibility'. ${ }^{26}$ Hamilton proposed that the federal government should be given powers of direct taxation and the regulation of trade. ${ }^{27}$ This would provide the Union with sufficient credit to raise funds as needed for the prosecution of the war and other necessary responsibilities of government. ${ }^{28}$

Hamilton left active service after the American victory at Yorktown, returned to New York, and set out immediately to secure a general convention to strengthen the Articles of Confederation that had governed the United States throughout the var. There was 'something noble and magnificent', he believed, 'in the perspective of a great Federal Republic, closely linked in the pursuit of a common interest, tranquil and prosperous at home, respectable abroad', and there is 'something proportionably diminutive and contemptible in the prospect of a number of petty states, with the appearance only of union, jarring, jealous and perverse, without any determined direction, fluctuating and unhappy at home, weak and insignificant by their dissentions, in the eyes of other nations'. ${ }^{29}$ Hamilton had identified the central element in the future success of the United States, and the greatest difference for the next two centuries between the United States and other constitutional republics. As a federation, the United States would need sufficient power to control and regulate its constituent states, or none of them would long succeed in a hostile world. ${ }^{30}$

The argument for continentalism began with the commonwealths of Greece, whose failure to unite raised 'pain and disgust' in Hamilton, contemplating the excesses of their 'usurping demagogues' and tyrants. ${ }^{31}$ When Hamilton and his fellow Continental Army officers united after the war to preserve 'those exalted rights and liberties of human nature for which they... fought and bled', they

21 A. Hamilton, The Continentalist No. I, in The New-York Packet, and the American Advertiser (12 July 1781), in Hamilton, Writings, 99.

22 The Continentalist No. I, 99.

23 The Continentalist No. I, 100.

24 The Continentalist No. I, 100.

25 A. Hamilon, The Continentalist No. III, in The New-York Packet, and the American Advertiser (9 August 1781), in Hamilton, Writings, 104.

26 The Continentalist No. III, 104.

27 A. Hamilton, The Continentalist No. IV in The New-York Packet, and the American Advertiser (30 August 1781), in Hamilton, Writings, 107.

28 The Continentalist No. IV, 108.

29) A. Hamilton, The Continentalist No. VI, in The New-York Packet, and the American Advertiser

(4 July 1782), in Hamilton, Writings, 118.

30 The Continentalist No. III, $101 \mathrm{ff}$.

31 The Continentalist No. I, 100. 
looked to Rome for their model in the character of Lucius Quinctius Cincinnatus, before securing to serve the republic, and then returned to his farm-but no courted popularity at the of the Roman demagogue Spurius Maelius, who had called themselves) pledged, with 'unalterable determination to prexander Hamilton in the chair, to preserve their that Union... so essentially promote and cherish, between the respective states, the American empire'. ${ }^{33}$

\section{Constitutionalism}

Hamilton himself, writing as 'Phocion', appealed to the people of New York to defend the true 'spirit of Whiggism' - or 'legal liberty' - against 'arbitrary acts of Athenian Phece' and 'the lawless combinations of unauthorized individuals'. ${ }^{34}$ The faced down the dis personal austerity, who life. ${ }^{35}$ Hamilton wrogues of Athens, and eventually paid for this probity with his and 'the most solemn (as he explained) to protect the Constitution of New York 'violence of rash and unprinations' of the peace treaty with Britain against the to preserve was the ancint coled men'. ${ }^{36}$ The principle that Hamilton sought 'disfranchised or defrauded of common-law doctrine that no person should be except by the law of the land any ... rights or privileges under the Constitution,

The Constitution of $\mathrm{New}$ (he judgment of his peers'. 37

guaranteeing trial by the 'New York, as interpreted by Hamilton, in explicitly process of law' described of the land', thereby also implicitly secured the 'due Carta. ${ }^{38}$ Hamilton's claim of 'Wh Edward Coke in his commentary on Magna to Magna Carta all illustrate Whiggism', his citation of Coke, and his reference Hamilton claimed as a 'Cine extent to which the Roman tradition that 'Phocion' both supple 'Cincinnatus' and the Greek probity that he claimed as the British colonies. to the 'heat and violence' tion' and 'solemn enger of 'momentary passions'. 40 The 'barriers of the constitutowards 'usurpation' and 'conts of the United States' should restrict the tendency

32 Institution of the Society of the Cincinnati (10 May 1783).

33 Institution of the Society of the Cincinnati.

34 A. Hamilton, A Letter from Phocion to the

Day (January 1784), in Hamilton, Writings, 127 .

35 L. Mestrius Plutarchus, Phocion, trans, 127.

Hamilton took detailed notes from Plutarans. J. Dryden, in The Lives of Noble Grecians and Romans. Hamilton's Pay Book (1777), ed. E. P. Pan in the pay book he kept as a Captain of Artillery: Alexander

36 Letter from Phocion, 127. E. P. Panagopoulos (Detroit: Wayne State, 1961).

38 Letter from Phocion, $127 . \quad 37$ Letter from Phocion, 128.

39 Letter from Phocion, 129.

41 Letter from Phocion, $129 . \quad 40$ Letter from Phocion, 128. 
equal rights and privileges for all ${ }^{42}$ and a constant respect for the 'fundamentals of the constitutions', including the constitution of the Federation itself. ${ }^{43}$ This remained the primary weakness in the post-war United States-not so much imbalances in the constitutions of the states themselves, although these certainly existed, as in their collective federal institutions, which Hamilton thought too weak to fulfil their basic obligations to Americans (in any of the states), or to the world. ${ }^{44}$

Alexander Hamilton took the lead, as a New York commissioner at a meeting of state delegates at Annapolis in 1786, in calling for a new convention, with 'more enlarged powers' to be held in Philadelphia the following May. ${ }^{45}$ The 'Address of the Annapolis Convention', as drafted by Hamilton, and circulated to the states, requested a 'general meeting of the States' to 'devise such further provisions as shall appear to them necessary to render the constitution of the Federal Government adequate to the exigencies of the Union'. ${ }^{46}$ Hamilton himself would become a New York delegate to this 'Constitutional Convention' in the summer of 1787. As the representative of a lightly settled and politically divided state, Hamilton did not play a prominent role in the proceedings, but he did make a long and detailed speech to the convention on 18 June, in which he set out his own proposals for reforming the federal government. The debates in the convention were kept secret, but records maintained by James Madison and Robert Yates give a good sense of Hamilton's views on the Federal Constitution, as frankly expressed to his colleagues. ${ }^{47}$

Hamilton had no illusion in the Constitutional Convention that he could significantly influence the deliberations, nor did he expect his remarks to be made public, so they were extraordinarily frank, and give a clearer sense of Hamilton's personal views than some of his more public remarks. His first and most important desire, as always, was to strengthen the federal government at the expense of the states, ${ }^{48}$ in order to check the 'ambitions of demagogues' ${ }^{49} \mathrm{Ham}$ ilton believed that a certain measure of military force would always be necessary to protect national unity (as demonstrated by contemporary insurrections in Massachusetts) and gave the usual examples of Greece and Germany to illustrate the costs of disunion. ${ }^{50} \mathrm{He}$ would have been perfectly happy to reduce the states to provinces, to save the expense of their separate governments. ${ }^{51}$ Hamilton wanted federal institutions to replicate the excellence of the mixed and balanced constitution of English liberty (already established in most of the states), rather than to preserve the parochial sovereignties of the separate states themselves. ${ }^{52}$ Hamilton

${ }^{42}$ Letter from Phocion, 130.

43 Letter from Phocion, 132.

44 Letter from Phocion.

45 Address of the Annapolis Convention (17 September 1786), in Hamilton, Writings, 144.

46 Address of the Annapolis Convention, 144.

47 James Madison's and Robert Yates's accounts were not released for more than fifty years after they were written, but are now available online and in Hamilton, Writings, $151 \mathrm{ff}$. (Madison) and 159 ff. (Yates).
48 Writings, 151
49 Writings, 152.
51 Writings, 155.
52 Writings, 156.
50 Writings, 153. 
remained an enthusiastic 'republican', like other Americans of his era, but also (like

his contemporaries) 'as loud as any in declaiming against the vices of democracy'.53

The virtue of the British constitution, as Hamilton and many of his contemporaries understood it, was its ability to unite 'public strength' with 'individual control the 'violence and the similar 'checks' in the American Constitution to ilton a strong advocate of a bicamere of the 'democratic spirit'. This made Hamextremely long terms in office, perh serfist senate, serving for serving for life. ${ }^{55}$ Hamilton believed for life, and for an elected executive, also electing senators and executive officers for such stable republican governments, guard against the 'popular passions' irresistible'. ${ }^{56}$ Hamilton well understood spread like wild fire' and 'become terms of office at the federal level, given the impossibility of creating such long but made his point anyway, in a spirit of resigne of contemporary public opinion, ism, desire for an executive veto, and commitment dechment. ${ }^{57}$ In his bicameralgovernment, Hamilton simply endorsed the enlightened consensus of his eres in

\section{Federalism}

The United States Constitution, when it emerged from Philadelphia, differed in many ways from Hamilton's ideals, as he expressed them in the Convention; nor did it correspond with New York public opinion, from which Hamilton in any case remained estranged. But he embraced the constitution immediately and worked tirelessly to secure its ratification, because it strengthened the federal government with new powers over commerce, foreign affairs, and above all taxation, to fulfil the the ratification movement in New York, and a 'Publiss', upon himself to organize and James Madison, wrote The Federalist, a series 'Publius', with the help of John Jay the constitution against its critics-essays which of essays explaining and defending influence on public understanding of the document. Written to persuad continuing contemporaries, The Federalist gives clear insights into what Hamilton and other eighteenth-century Americans thought important in constitutional government, and how the United States Constitution sought to secure these purposes. ${ }^{59}$

The first number of The Federalist appeared on October 27, 1787, in New York's Independent Journal, at a time when the fate of the Federal Constitution remained very much in doubt. The Confederation Congress had transmitted the proposed constitution to the states in September, with a call for state conventions to consider ratification, but none had yet done so. Hamilton wrote in the character

5.3 Writings, 156.

56 Writings, 157.

54 Writings, quoting Jacques Necker.

57 Writings, 158-9. 58 Writings, 165

55 Writings, 157.

59 James Madison considered The Federalist "the most authentic exposition

Constitution, as understood by the Body which the most authentic exposition of the text of the Federal Madison to Thomas Jefferson 8 Frepared and the authority which accepted it'. James York: G. P. Putnam's Sons, 1900-10), Writings of James Madison, ed. G. Hunt (New 
of 'Publius', co-founder with Brutus of the Roman republic, and champion of the 'imperium populi' or 'sovereignty of the people'. ${ }^{60}$ The declared purpose of The Federalist was fourfold: first, to demonstrate that 'societies of men are really capable... of establishing good government from reflection and choice';61 second, to expose the errors and 'ambition' of local politicians opposed to a closer union; 62 third, to show that 'vigour of government is essential to the security of liberty'; 63 and fourth, to demonstrate 'the conformity of the proposed constitution to the true principles of republican government' ${ }^{64}$ Hamilton's great rival, Thomas Jefferson, would recognize The Federalist as 'the best commentary on the principles of government which was ever written', 65

The argument for Union, as repeated in The Federalist, began with the likelihood of 'domestic factions' and 'convulsions' within and between the states themselves. ${ }^{66}$ Here, as before, the negative examples were Greek, ${ }^{67}$ supplemented by England, France, and now the recent experience of Massachusetts and the rebellion of Daniel Shays. ${ }^{68}$ Given the histories of Sparta, Athens, Rome, and Carthage, ${ }^{69}$ Hamilton denied that the 'genius of republics' was necessarily pacific or that 'perpetual peace' between neighbours would prevail without a strong federation to support it. ${ }^{70}$ Hamilton understood that Americans, like the rest of the world, were 'yet remote from the happy empire of perfect wisdom and perfect virtue'. ${ }^{71} \mathrm{He}$ quoted the Abbé de Mably to support his contention that the neighbouring states would be natural enemies, without a 'confederate republic' and federal constitution to extinguish the 'secret jealousy' that 'disposes all States to aggrandize themselves at the expense of their neighbours' ${ }^{72}$

Hamilton's reference to Mably's proposal for a public law of Europe illustrates the extent to which his first concern, as 'Publius', was already the project of substituting public law for international relations, at least on the North American continent. Territorial conflicts between Pennsylvania and Connecticut, ${ }^{73}$ New York

60 See T. Livius, Ab urbe condita, II.7.7. Cf. L Mestrius Plutarchus, Publicola. On 'Publius' and similar pseudonyms, see M. N. S. Sellers, American Republicanism: Roman Ideology in the United States Constitution (Basingstoke: Macmillan, 1994), 8-10.

61 The Federalist No. 1 in The Independent Journal (27 October 1787), in Ball, The Federalist, 1.

62 The Federalist No. 1, $2 . \quad 63$ The Federalist No. 1, 3.

64 The Federalist No. 1, 4, where these purposes are listed in somewhat starker form, along with their necessary corollaries.

65 Thomas Jefferson to James Madison, 18 November 1788 in Papers of Thomas Jefferson, ed. J. P. Boyd, C. T. Cullen, and J. Catanzariti (Princeton: Princeton University Press, 1950) vol. XIV, 188.

${ }^{66}$ The Federalist No. 6, in The Independent Journal (14 November 1787), in Ball, The Federalist, 19.

\footnotetext{
67 The Federalist No. 6, 20.

68 The Federalist No. 6, 21.

69 The Federalist No. 6, 22.

70 The Federalist No. 6, 21.
}

71 The Federalist No. 6, 24

72 The Federalist No. 6, 25, citing G. B. deMably, Principes des Négociations pour servir d'introduction au Droit Public de l'Europe (Amsterdam, 1757).

73 The Federalist No. 7 in The Independent Journal (17 November 1787), in Ball, The Federalist, 26. 
and Vermont, and others had already led to bloodshed, ${ }^{74}$ as might future commercial disagreements, ${ }^{75}$ and some states' recent repudiations of their public debt. ${ }^{76}$ Hamilton warned of 'war', 77 'plunder', and 'devastation'78 in the absence of a Continental Union, since only federation could protect separate states from the 'ambition' and 'jealousy' of their neighbours. ${ }^{79}$ Hamilton's desire here was not to overcome or deny ambition through the agency of a federal government, but rather to harness it to make the vigilance of the collected states in the Union a barrier against 'domestic faction' or 'insurrection' in any of their members. ${ }^{80}$

Hamilton's federal constitutionalism rested on his settled conviction that 'a Firm Union' would be of 'utmost moment to the peace and liberty of the States' . 81 The history of the 'petty Republics of Greece and Italy' excited his 'horror and disgust' at their 'rapid succession of revolutions', their 'extremes of tyranny' and their 'tempestuous waves of sedition and anarchy'. In contrast (the reference is to Rome), 'stupendous fabrics reared on the basis of liberty' have 'flourished for ages', 82 through 'ENLARGEMENT of the ORBIT within which such systems... revolve either in respect to the dimensions of a single State, or to the consolidation of several smaller States into one great confederacy'. ${ }^{83}$ Hamilton cited the Baron de Montesquieu to support his claim that the institution of a 'confederate republic' could secure the primary advantages of monarchy, by 'extending the sphere of popular government'. 84 A 'confederate Republic', as Hamilton understood the term, signified the association of several states into one larger and more powerful Union. ${ }^{85}$ Hamilton claimed that this arrangement could prevent the encroachment of any single member against the rest, while quelling 'popular insurrections' that might arise in any of the constituent republics. ${ }^{86}$

\section{Republicanism}

The Federalist set out to demonstrate 'the conformity of the proposed constitution to the true principles of republican government'. ${ }^{87}$ The term 'republic' was synonymous, for Hamilton, as for all Americans of his age, ${ }^{88}$ with 'civil liberty'

\footnotetext{
74 The Federalist No. 7, 27.

76 The Federalist No. 7, 30.

75 The Federalist No. 7, 28.

77 The Federalist No. 8, in The New-York Packet (20 November 1787), in Ball, The Federalist, 30.

78 The Federalist No. 8, 31 . 79 The Federalist No. 8, 34.

80 The Federalist No. 9 in The Independent Journal (21 November 1787), in Ball, The Federalist, 35.

81 The Federalist No. 9, $35 . \quad 82$ The Federalist No. 9, 35.

83 The Federalist No. 9, 36. 84 The Federalist No. 9, 37.

85 The Federalist No. 9, 39.

86 'Publius' [Alexander Hamilton] The Federalist No. 9, 30, quoting at length from Montesquieu, Charles Louis de Secondat, baron de la Brède et de, De L'Esprit des lois (1748), Book VIII, chapter 16.

87 'Publius' [Alexander Hamilton], The Federalist No. 4.

88 Cf. George Washington, 'The First Inaugural Speech' (30 April 1789), in George Washington: A Collection, ed. W. B. Allen (Indianapolis: Liberty Fund, 1988), $460 \mathrm{ff}$.
} 
and 'free government'. ${ }^{89}$ This required elections, of course, as Hamilton had recognized at the Constitutional Convention, ${ }^{90}$ but also further guarantees, to be discovered by applying 'the science of politics' to the circumstances of the North American states. ${ }^{91}$ Hamilton identified several useful principles of constitutional government now known to 'the enlightened friends of liberty' that 'were either not known at all, or imperfectly known to the ancients'. These included 'The regular distribution of power into distinct departments - the introduction of legislative balances and checks - the institution of courts composed of judges holding their offices during good behaviour-[and] the representation of the people in the legislature by deputies of their own election'. ${ }^{2}$

Hamilton's list of 'new discoveries' and political ideas that 'have made their principal progress towards perfection in modern times' 93 provided republicans (Hamilton believed) with the 'means, and powerful means' through which 'the excellencies of republican government may be retained and its imperfections lessened or avoided'. ${ }^{44}$ Hamilton's originality lay not so much in this list, which corresponded very closely to a similar list provided by John Adams in his Defence of the Constitutions of Government of the United States of America, ${ }^{95}$ as it did in his addition of federalism to the basic protections of republican government. ${ }^{96} \mathrm{Ham}-$ ilton promoted 'the utility of confederacy' not only 'to suppress faction', but also 'to guard the internal tranquility of states', and 'to increase their external force' against others. ${ }^{97} \mathrm{~A}$ 'vigorous executive' in a republican confederation would provide a constant protection against the assaults 'of ambition, of faction, and of anarchy'. ${ }^{98}$

The American model for successful republican government was Rome, but Rome itself had succumbed to 'absolute power', the 'tyranny' of 'ambitious individuals', and the 'seditions of whole classes of the community'. ${ }^{99}$ Even in its republican days, as Hamilton well understood, 'Rome was never sated of carnage and conquest'. ${ }^{100}$ How, then, to improve upon the ancient model, but by 'reason and good sense'?101 Free trade among the states would make them all richer, stronger, and more creditable to foreigners, ${ }^{102}$ more amenable to taxation, ${ }^{103}$ and economically prosperous, ${ }^{104}$ provided that the federal government took authority to rule directly over individuals, not indirectly, as when acting through the states. ${ }^{105}$

89 The Federalist No. 9, 35.

90 See Madison's notes on Hamilton's remarks at the Constitutional Convention, in Hamilton, Writings, 157.

91 The Federalist No. 9, 36. 92 The Federalist No. 9, 36

93 The Federalist No. 9, 36. 94 The Federalist No. 9, 36

95 Adams, Defence of the Constitutions of Government, i.

96 The Federalist No. 9, 36. 97 The Federalist No. 9, 36.

98 The Federalist No. 70 in The Independent Journal (15 March 1788), in Ball, The Federalist, 341.

99 The Federalist No. 70, 341. 100 The Federalist No, 6, 22.

101 The Federalist No. 70, 343. $\quad 102$ The Federalist No. 11, 51.

103 The Federalist No. 12, $53 . \quad 104$ The Federalist No. 13, 57.

105 The Federalist No. 15, 67. 
Hamilton's desire to strengthen the federal government carried with it the necessary corollary that federal institutions should also be protected by all the republican checks and balances against arbitrary power already being applied in the states. ${ }^{106}$ If the federal government were to act directly on individuals, as Hamilton desired that it should, with the ability to apply sanctions through its laws, ${ }^{107}$ then it ought also be subject to independent courts, ${ }^{108}$ and rest in all the the people', which Hamilton considered to be legitimate authority'. ${ }^{109}$

Alexander Hamilton understood the United States of America, as established under the Constitution of 1787 , to be a 'republic', but specifically a 'confederate' republic, ${ }^{110}$ existing primarily for certain purposes, including 'the common defence of the members - the preservation of the public peace as well against internal convulsions as external attacks-the regulation of commerce with other nations and between the States-[and] the superintendence of... intercourse, political and commercial, with foreign countries'. ${ }^{111}$ As to these purposes, the federal republic would need 'all the powers, which a free people ought to delegate to any government.' ${ }^{12}$ Hamilton supposed it likely, in any case, that the federal government would enjoy better administration than the governments of the states, because it would have a 'greater knowledge' and 'more extensive information' to draw on..$^{113}$ The government of the United States would be 'less apt to be tainted by the spirit of faction, and more out of the reach of those occasional ill humors or temporary prejudices... which in smaller societies frequently contaminate the public councils'

\section{The Rule of Law}

Alexander Hamilton praised the new Constitution of the United States as the 'supreme law of the land', superior to the laws and constitutions of all the several states in the Union. ${ }^{115}$ The legislatures, courts, and magistrates of all member States were to be 'incorporated into the operations of the national government' as 'during good behaviour' 'during good behaviour' - 'one of the most valuable of the modern improvements in the practice of government'. ${ }^{117}$ Tenure during good behaviour (secured in England by the Act of Settlement in 1701) had proved under monarchy to be 'an excellent barrier to the despotism of a prince'. Hamilton suggested that in a republic it would

106 The Federalist No. 71, 350.

108 The Federalist No. 22, 104.

110 The Federalist No. 9, 38.

112 The Federalist No. 23, 109

113 The Federalist No. 27, 125.

115 The Federalist No. 27, 127.

117 The Federalist No. 78, 377.
107 The Federalist No. 21, 94.

109 The Federalist No. 22, 104.

111 The Federalist No. 23, 106.

is in original).

114 The Federalist No. 27, 125

116 The Federalist No. 27, 127. 
be 'no less excellent' as a 'barrier to the encroachments and oppressions of the representative body'. ${ }^{118}$

Hamilton praised judicial independence as 'the best expedient which can be devised in any government, to secure a steady, upright and impartial administration of the laws'. ${ }^{19}$ Supporting, as he did, a general separation between the legislative, executive, and judicial branches of government ${ }^{120}$ and a constitutional system of checks and balances to control them all, Hamilton identified judges as the "least dangerous' of the constitutional powers. ${ }^{121}$ The judiciary has no power over the sword (controlled by the executive), or the purse (controlled by the legislature). Judges have (he explained) 'neither force nor will, but merely judgment' and will need 'permanency in office' to protect the 'freedom and independence' of their judgments against coordinate branches of government. ${ }^{122}$ Hamilton suggested that independent judges best protect 'the citadel of public justice and the public security' and insisted that 'complete independence of the courts of justice' is 'neculiarly essential' for a limited constitutional government. ${ }^{123}$

Limited constitutions can persist in practice, Hamilton believed, and control the excesses of legislative authority only through the courts of justice, 'whose duty it must be to declare all acts contrary to the manifest tenor of the constitution void'. Without this 'all the reservations of particular rights' would amount to nothing. ${ }^{124}$ Hamilton insisted that judges must have the power to pronounce legislative acts 'void', because otherwise legislators would become sole arbiters of their own constitutional powers, with licence to surpass constitutional limitations at will. 'A constitution is in fact, and must be regarded by the judges as a fundamental law.' This made interpretation 'the proper and peculiar province' of courts. Hamilton as 'Publius' repeated that judges alone should settle the meaning of the constitution, and all laws made pursuant to its authority. ${ }^{125}$ '[W] here the will of the legislature, declared in its statutes, stands in opposition to that of the people declared in the Constitution... [then] judges ought to regulate their decisions by the fundamental laws, rather than by those which are not fundamental.' ${ }^{126}$

Hamilton's commitment to judicial independence as the primary protection of the rule of law reflects centuries of English history (and French philosophy), but also his own experience of American justice. Only the 'permanent tenure' of judges could secure the 'bulwark' of the constitution against legislative 'encroachments'. ${ }^{127}$ Hamilton considered the independence of judges 'equally requisite' to protect the rights of individuals against 'designing men' and 'serious oppressions'. 128 'Until the people have by solemn and authoritative act annulled or changed the established

118 The Federalist No. 78, 377.

119 The Federalist No. 78, 377.

120 The Federalist No. 78, 378, quoting Montesquieu, Book XI, chapter 6 .

121 The Federalist No. 78, 378. 122 The Federalist No. 78, 378.

123 The Federalist No. 78, 378, 124 The Federalist No. 78, 379.

125 The Federalist No. 78, 379. 126 The Federalist No. 78, 380.

127 The Federalist No. 78, 381. 128 The Federalist No. 78, 381. 
form, [the Constitution] is binding upon them collectively, as well as individually, and no presumption, or even knowledge of their sentiments, can warrant their representatives in a departure from it. ${ }^{\prime 29}$ No such protection could be expected, Hamilton believed, without independent judges, secure in their tenure of office, ${ }^{130}$ and well enough paid to justify the renunciation of ordinary legal practice. ${ }^{131}$

Alexander Hamilton's 78th letter as The Federalist offered a paean to judges, judicial independence, and constitutionalism, which has had an enormous influence in strengthening the resolution of judges in the United States and elsewhere to maintain the rule of law against legislative enthusiasm. The practice of judicial review of legislation, perpetuated by United States Supreme Court Chief Justice John Marshall in the famous case of Marbury v Madison, closely followed the reasoning of The Federalist. ${ }^{132}$ The Federalist also reinforced the prohibition of ex post facto laws and sanctity of the writ of habeas corpus as essential 'securities' to 'liberty' and 'republicanism' against 'arbitrary government'. ${ }^{133}$ 'The establishment of a constitution,' Hamilton asserted, 'by the voluntary consent of the whole people, is a PRODIGY, to the completion of which I look forward with trembling anxiety. ${ }^{\prime 34}$ For Hamilton, the primary virtues of the Constitution of the United States were the unity, energy, justice, and legality that federal republican institutions would bring to government, throughout the Union.

\section{Conclusion}

The systematic exposition of Hamilton's constitutional thought ended with the entry into force of the United States Constitution, and the election of George Washington as President of the United States, with Hamilton as his Secretary of the Treasury and de facto chief of staff. Henceforth, Hamilton's primary concerns would be the practical problems of consolidating a federal republic from what had been a loose society of states. Hamilton's Report on Public Credit established the necessity of a sound public debt. ${ }^{135}$ His Report on a National Bank secured the finances of the United States. ${ }^{136}$ Both required constitutional support, but only as related to their relationship with the states, and Hamilton had no difficulty getting the best of that argument. ${ }^{137}$ His Report on the Subject of Manufactures laid the groundwork for the subsequent prosperity of the Union, ${ }^{138}$ and his tenacity in the newspapers defeated the most persistent opponents of the federal project. ${ }^{139}$

129 The Federalist No. 78, 381-2.

130 The Federalist No. 78, 382.

131 The Federalist No. 79, 384.

1.33 The Federalist No. 84, 418.

132 Marbury v Madison, 5 U.S. 137 (1803).

135 Alexander Hamilton, Report on Publi The Federalist No. 85, 431.

136 Report on

137 Report on a National Bank (13 December 1790). Hamilton, Writings, 759.

138 Alexander Hamilton, Report on the Subject of Manufactures (5 December 1791).

139 See his response as 'An American' to the machinations of 'State-power' against 'National Authority' in 'An American' [Alexander Hamilton], For the Gazette of the United States (4 August 1792). 
Hamilton would continue, both in and out of office, to take to the lists as 'Pacificus', 140 'Tully', 141 'Titus Manlius', 142 and so forth, in defence of 'an inviolable respect for the Constitution and the laws' as the 'greatest source of security in a Republic'. ${ }^{143}$ As his carefully chosen Roman pseudonyms attest, Hamilton kept faith with the old Roman conception of balanced republican government against democratic and self-interested 'anarchy', (towards which 'contempt of the laws is the high road'). ${ }^{144}$ Hamilton distinguished a 'government of FORCE' or 'despotism' from a 'government of LAWS', or 'liberty', and insisted on the 'obvious truth' that 'a sacred respect for the constitutional law is the vital principle' of a 'free government'. ${ }^{145}$

'How long, ye Catilines,' Hamilton demanded as 'Tully', 'will you abuse our patience!' 146 Hamilton saw constitutional government in the United States beset by his enemies, and pursued them in print with philippics, to the point that they conspired at his downfall, and eventual death, like his Roman alter ego. ${ }^{147}$ Throughout his career, Hamilton acted on the principle that although the people

ommonly intend the public good', they 'do not always reason right about the means of promoting it'. ${ }^{148}$ The 'republican principle demands', he asserted, that the 'deliberate sense of the community' should govern their affairs, not 'every sudden breeze of passion' or 'every transient impulse which the people may receive from the arts of men'. The beauty of constitutional government lay in its ability to distinguish mere 'inclinations' from true 'interests' of the people. ${ }^{149}$

Alexander Hamilton shared the republican constitutional principles of his contemporaries, including their commitment to bicameral legislatures, elected executives, the separation of powers, checks and balances in government, and representative (rather than direct) democracy. He differed somewhat in his much stronger commitment to federalism, to executive power, and to judges, as the 'bulwark' of constitutional liberty. Hamilton became as 'Publius' (with Madison) in The Federalist the foremost advocate and interpreter of constitutional government as it would ultimately be implemented in the United States. All these principles, widely accepted in theory by 'enlightened' political writers of Hamilton's era, were made real in the American state constitutions, and the Federal Constitution of 1787, from which they have extended across the globe. Continentalist, federalist, republican, and devotee of the rule of law, it was as a constitutionalist that Hamilton left his greatest legacy. Great modern federations, such as

140 'Pacificus' [Alexander Hamilton], Pacificus No. I, in Gazette of the United States (29 June 1793), defending Washington's proclamation of neutrality.

${ }_{141}$ Tully No. I in Dunlap and Claypoole's American Daily Advertiser (23 August 1794), against attempts in Western Pennsylvania to defy the constitution's authority.

142 The Stand in the New York Commercial Advertiser (10 March 1798).

143 Tully No. III in Dunlap and Claypoole's American Daily Advertiser (28 August 1794).

144 Tully No. III. 145 Tully No. III.

146 Tully No. III.

147 See e.g. letter from Aaron Burr, 22 June 1804, in Hamilton, Writings, 1014-15.
148 The Federalist No. 71, 349.

149 The Federalist No. 71, 349 (emphasis added). 
the European Union, the Federal Republic of Germany, and even nominally monarchical Australia take their ambition and primary example from the American Federalists' creation of that 'stupendous fabric' of government, reared 'on the basis of liberty', that has 'flourished for ages' to the amazement and inspiration of the world. ${ }^{150}$

150 Cf. 'Publius' [Alexander Hamilton], The Federalist No. 9 in The Independent Journal (21 November 1787), republished in Ball, The Federalist, 35. 